\title{
Collection and Infrared Analysis of Rumen Gas in Cows
}

\author{
Takao Sarashina, Junichi T akahashi* \\ Shigeru ICHIJO and Satoshi OSAME \\ Department of Veterinary Internal Medicine, and *Department \\ of Animal Science, Obihiro University of Agriculture \\ and Veterinary Medicine, Obihiro 080, Japan
}

(Received August 21, 1989)

Key words : rumen gas, methane, carbon dioxide, infrared analysis

Rumen gases produced by the microbial fermentation in the rumen, mainly composed of carbon dioxide $\left(\mathrm{CO}_{2}\right)$ and methane $\left(\mathrm{CH}_{4}\right)$, reflect rumen function in ruminants ${ }^{1,2}$. Since the early 1970 's, the nutritional and physiolo-" gical significance of rumen gas production has been focused in view of improving the efficiency of utilization of feed energy ${ }^{3}$. In the investigation of rumen gases, quantitative analysis of $\mathrm{CH}_{4}$ can easily be carried out from respiratory gas ${ }^{4)}$ since all of $\mathrm{CH}_{4}$ appeared in the expired air are generated in the rumen. It is, however, difficult to distinguish between $\mathrm{CO}_{2}$ expired from the lungs and $\mathrm{CO}_{2}$ produced from rumen fermentation. In order to clarify the role of rumen gas in relation to the fermentation properties of feeds ingested in the rumen, the concentrations of these gases in the rumen should be determined directly.

\section{Materials and Methods}

In the present paper, rumen gases were analyzed spectrophotometrically by applying infrared respiratory gas analyzers ranging $0-7$ $\%$ for $\mathrm{CO}_{2}$ and $0-0.6 \%$ for $\mathrm{CH}_{4}$. However, $\mathrm{CO}_{2}$ and $\mathrm{CH}_{4}$ concentrations were too high for the analyzers. In consequence, a diluting apparatus (Fig. 1) becomes to be required. For the dilution of rumen gas collected, one 3-liter and two 23-liter polyethylene bottles were prepared. A pair of glass tube (outside diameter, $6 \mathrm{~mm}$ ) were inserted through the rubber plug of each bottle. The two 23-liter bottles were connected by a silicone tubing (inside diameter, $6 \mathrm{~mm}$ ). A gas sampler of which the sliding face was smeared with liquid paraffin to prevent gas leaks was joined to one branch of the $\mathrm{Y}$-shaped tube connected to one 23-liter bottle. The 3-liter bottle was joined to another branch of the Y-shaped tube to make gas homogeneous before analyzing. Distilled water $(2.2 \mathrm{l})$ and 1 liter of liquid paraffin (to prevent the absorption of $\mathrm{CO}_{2}$ gas into the distilled water) were poured into the right 23-liter bottle to make a 19.8-liter air space in the bottle. In the left 23 -liter bottle, 1 liter of liquid paraffin and 19.8 liters of distilled water were poured in. Two hundred $m l$ of rumen gas was directly collected into the gas sampler considered the dead space by paracentesis through the left paralumbar fossa of cows and mixed thoroughly with the air in the

牛の第一胃内ガスの採集および赤外線分析：更科孝夫・高橋潤一・一条 茂・納 敏

(帯広畜産大学畜産学部 带広市080) 


\section{Collection and Analysis of Rumen Gas in Cows}

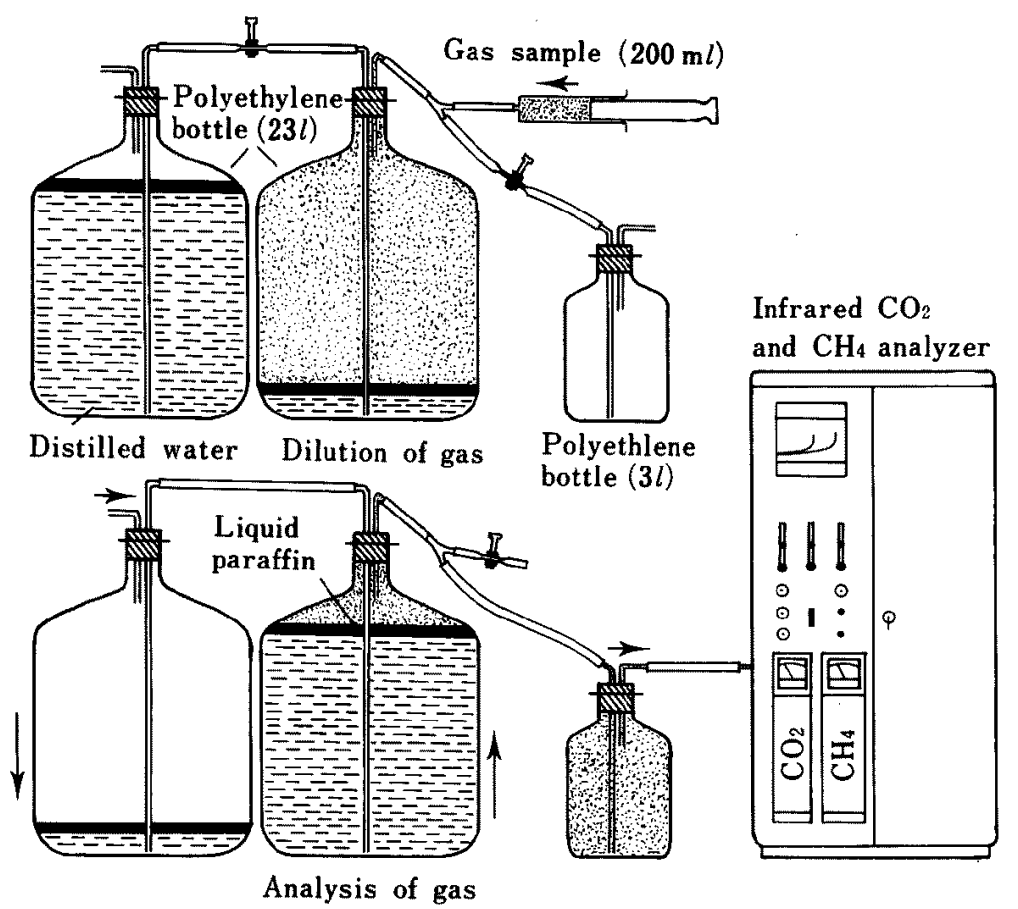

Fig. 1. Dilution method for rumen gas

right 23-liter bottle (upper part of Fig. 1) by pumping of the gas sampler at room temperature. The diluted rumen gas was then introduced into the infrared $\mathrm{CO}_{2}$ and $\mathrm{CH}_{4}$ analyzers (HORIBA VIA-300) (bottom part of Fig. 1). Gas analyses were finished within 20 min when the peak values of $\mathrm{CO}_{2}$ and $\mathrm{CH}_{4}$ recorded on the chart (chart speed, $6 \mathrm{~mm} / \mathrm{sec}$ ) showed the plateau levels. From the values of the plateau levels, $\mathrm{CO}_{2}$ and $\mathrm{CH}_{4}$ concentrations in the rumen were calculated including the dilution multiple. The $\mathrm{CO}_{2}$ concentration was corrected subtracting $\mathrm{CO}_{2}$ concentration of the air in the right 23 liter-bottle before the dilution. To examine the effects of feeds on the $\mathrm{CO}_{2}$ and $\mathrm{CH}_{4}$ concentrations in the rumen gas, two dry cows were maintained on 5 rations ; hay, wilted grass silage, corn silage, a mixed ration of corn silage and concentrates or a mixed ration of wilted grass silage, corn silage and concentrates. Rumen gases were collected 2, 4, 6 and $12 \mathrm{~h}$ after feeding under a fixed regimen of feeding ( $7: 00$ and $19: 00)$.

\section{Results and Discussion}

The resting values of $\mathrm{CO}_{2}$ and $\mathrm{CH}_{4}$ concentrations in the rumen before feeding were as follows : $56.6 \%$ and $31.7 \%$ on hay, $52.1 \%$ and $34.6 \%$ on wilted grass silage, $57.1 \%$ and $32.0 \%$ on corn silage, $59.0 \%$ and $32.0 \%$ on a mixed ration of corn silage and concentrates, and 55.7 $\%$ and $34.5 \%$ on a mixed ration of wilted grass silage, corn silage and concentrates respectively. The $\mathrm{CO}_{2}: \mathrm{CH}_{4}$ ratios tended to increase rapidly and peaked 2-4 $\mathrm{h}$ after feeding, and then decreased gradually to the resting levels. Mean values of $\mathrm{CO}_{2}: \mathrm{CH}_{4}$ ratio showed the highest value when the cows fed on corn silage. Relatively lower values were observed in hay and wilted silage. For the two mixed rations, the ratios were between the values for corn silage and hay or wilted grass silage. These tendencies agree well with the results of the manometric determinations for these rumen 


\section{Sarashina, Takahashi, ICHIJO and Osame}

gases reported previously by Brody ${ }^{5)}$.

\section{References}

1) Thornton, J.H. and F.N. Owens, J. Anim Sci., 52 : 628-634. 1981.

2) Miltimore, J.E. and J.M. MCARthur, Nature, 196 : 288-289. 1962.
3) Trei, J.E., G.C. ScotT and R.C. PARISh, J. Anim. Sci., $34: 510-515.1972$.

4) Takahashi, J., T. Chiba, T. Endo, J. Ikariga and H. Fusit A, Proc. Vth World Confer. Anim. Prod. 2, 351-352. 1983.

5) BRoDY, S., Bioenergetics and Growth, 383. Reinhold Publ., New York. 1964. 